\title{
Aerobic degradation of phytoplankton debris dominated by Phaeocystis sp. in different physiological stages of growth
}

\author{
Ronald Osinga $^{1, *}$, Koert A. de Vries ${ }^{1}$, Wilma E. Lewis ${ }^{1}$, Wim van Raaphorst ${ }^{1}$, \\ Lubbert Dijkhuizen ${ }^{2}$, Fleur C. van Duyl ${ }^{1, * *}$
}

\author{
${ }^{1}$ Netherlands Institute for Sea Research, PO Box 59, 1790 AB Den Burg (Texel), The Netherlands \\ ${ }^{2}$ University of Groningen, Department of Microbiology, PO Box 14, 9750 AA Haren, The Netherlands
}

\begin{abstract}
The aerobic degradation of phytoplankton debris collected in Dutch coastal waters on 2 days in 1991 (15 April and 8 May), representing 2 physiological stages of a phytoplankton spring bloom dominated by Phaeocystis sp., was studied in batch culture experiments. The bacterial production and the concentrations of particulate organic carbon (POC) and dissolved organic carbon (DOC) were monitored over a period of $102 \mathrm{~d}$. Bacterial numbers and biomass were followed for $35 \mathrm{~d}$. All experiments showed a rapid metabolic response of bacteria and a sharp decrease in the concentration of POC and DOC during the first days of the experiments. Thereafter, bacterial production rates remained constant, and POC and DOC decreased slowly. Apparently, the phytoplankton debris consisted of a labile, rapidly degradable fraction and a refractory, slowly degradable fraction. The labile fraction comprised approximately $50 \%$ of the debris, and was degraded with a bacterial carbon conversion efficiency of between 10 and $20 \%$. There were no indications that antibiotic compounds present in the algal debris inhibited the degradation. Acrylate, a proposed antibiotic compound which was present in the algal debris, was rapidly degraded in a control experiment. The percentage of the material that had been degraded after $102 \mathrm{~d}$ was highest in the experiment with material collected in May. It was concluded that during the early phase of the bloom, more refractory compounds are produced.
\end{abstract}

KEY WORDS: Phaeocystis sp. Bacterial degradation · Organic carbon

\section{INTRODUCTION}

The colony-forming alga Phaeocystis sp. (Haptophyceae) dominates the algal spring bloom in the southern North Sea (Cadée \& Hegeman 1986, Lancelot \& Mathot 1987). During these blooms, excessive foam formation can be observed on beaches (Lancelot et al. 1987). The social aspects of this foam formation and the ecological significance of Phaeocystis sp. as a producer of organic matter have made this species the subject of intensive studies (Veldhuis 1987, Van Boekel 1993, Lancelot \& Wassmann 1994).

\footnotetext{
- Present address: Wageningen Agricultural University, Department of Food Sciences, PO Box 8129, 6700 EV Wageningen, The Netherlands

*Addressee for correspondence. E-mail: duyl@nioz.nl
}

However, more information is needed for a proper understanding of the carbon cycle in Phaeocystisdominated ecosystems. Microbial degradation of organic matter derived from Phaeocystis spp., a key process in the carbon cycle, is still not well understood. Detailed information on the biodegradability of organic matter produced during blooms of Phaeocystis spp. is lacking. In addition, the interactions between Phaeocystis spp. and bacteria are unclear: the colony material seems to be better protected against bacterial attack during the exponential growth phase of these algae than in later stages of the bloom. The chemical composition of the colony material, however, does not indicate a change in degradability in the course of the bloom (Thingstad \& Billen 1994). Inhibition of microbial degradation may be due to the production of antibiotic compounds by the algae. The production of 
acrylate by Phaeocystis spp. has repeatedly been reported in this respect (Sieburth 1960, Eberlein et al. 1985, Slezak et al. 1994) At present, however, there are no experimental data on degradation of Phaeocystis spp. material to support this theory

In this study, the decay of dead algal material, collected during 2 different stages of a Phaeocystis sp. spring bloom in Dutch coastal waters, was followed in batch culture experiments. The main objectives of this study were (1) to provide data on the biodegradability of organic matter produced in Phaeocystis-dominated phytoplankton blooms, and (2) to see whether the degradability changes during the development of a Phaeocystis sp. bloom. In addition, we investigated the possible role of acrylate as an inhibiting agent for microbial activity.

\section{MATERIAL AND METHODS}

Algal debris. Algal debris was collected with plankton nets (mesh $50 \mu \mathrm{m}$ ) in the western Dutch Wadden Sed on 2 days in 1991, representing the exponential growth phase (15 April) and the stationary phase (8 May) of a Phaeocystis sp. spring bloom (Cadée \& Hegeman 1993). The procedure for the collection of the algal debris was described in detail by Van Duyl et al. (1992)

Microscopic counts carried out by Cadée \& Hegeman (1993) in the Marsdiep (the tidal inlet between the North Sea and the western Dutch Wadden Sea) showed that Phaeocystis sp. and diatoms were the major components of the algal population on 15 April and 8 May. Other microalgal species were not present in significant numbers. Based on the counts of Cadée \& Hegeman (1993), we estimated the contribution of Phaeocystis sp. to total organic carbon at $\sim 50$ and $\sim 80 \%$ for 15 April and 8 May, respectively.

Small subsamples $(-30 \mathrm{ml})$ of the algal debris were dried at $60^{\circ} \mathrm{C}$ in an oven for analysis of the organic carbon and nitrogen content. The dried material was ground by hand in a mortar, and subsamples of $\sim 3 \mathrm{mg}$ were analysed on a Carlo Erba N 1500-2 elemental analyser according to Verardo et al. (1990). The rest of the debris was stored at $-20^{\circ} \mathrm{C}$, and was thawed just before the experiments started.

The concentration of acrylate in the algal debris was measured on a Waters 600E high performance liquid chromatography (HPLC) system (Osinga et al. 1995).

Experiments. To simulate degradation in sea water, the algal debris was diluted 10-fold with $0.2 \mu \mathrm{m}$ filtered oligotrophic sea water from the northern North Sea. The diluted debris was incubated in open, oxic batch cultures (culture volume: 2 l) that were mixed with a magnetic stirrer. The cultures were aerated (about $0.51 \mathrm{~min}^{-1}$ ) via a plastic tube that had its outflow approximately $5 \mathrm{~cm}$ above the bottom of the culture flasks. To study the influence of the physiological stage of the algal bloom, debris collected on 15 April was incubated separately from debris collected on 8 May. We will refer to these separate incubations as 'April' and 'May' A small amount ( $8 \%$ of the total culture volume) of $5.0 \mu \mathrm{m}$ filtered sea water from the Marsdiep was added to inoculate the cultures with a fresh bacterial and nanozooplankton population. The cultures were incubated in the dark at a constant temperature of $12 \pm 0.5^{\circ} \mathrm{C}$. All experiments were carried out in duplicate. Wilcoxon's signed rank test was applied to test whether significant differences occurred between replicate data series.

The degradation of the algal debris was measured by following the concentrations of particulate organic carbon (POC) and dissolved organic carbon (DOC) in the cultures for a period of $102 \mathrm{~d}$. Samples for POC and DOC analysis were taken from the cultures with a Gilson Pipetman, using tips with an opening of $3 \mathrm{~mm}$ in diameter. Before sampling, the incubation flasks were shaken by hand to homogenize the culture. Sampling frequency was reduced during the experiment from daily in the first week to once every $2 \mathrm{wk}$ in the second half of the experiment.

The sample size for POC analysis was 0.5 or $1.0 \mathrm{mI}$. Samples were gently pushed through a GFF glassfibre filter (pore size $0.7 \mu \mathrm{m}$, diameter $10 \mathrm{~mm}$ ) with an injection syringe. Before use, these filters were decarbonated at $520^{\circ} \mathrm{C}$ for $12 \mathrm{~h}$ and weighed. After filtration. filter and residue were dried at $60^{\circ} \mathrm{C}$ for $12 \mathrm{~h}$ and weighed again. The organic carbon and nitrogen content was measured on a Carlo Erba NA 1500-2 elemental analyser (Verardo et al. 1990). Samples were not acidified with sulfurous acid: analysis of identical algal debris samples with and without this acidification step showed that the carbonate concentration in this material was negligible.

The sample size for DOC analysis was $1.0 \mathrm{ml}$. After dilution with $4.0 \mathrm{ml}$ distilled water, samples were filtered over decarbonated GFF filters under gentle suction (maximum pressure $0.3 \mathrm{bar}$ ). Three subsamples of $1.0 \mathrm{ml}$ were taken from the filtrate for analysis on an Oceanography International $0524 \mathrm{~B}$ total carbon system, using the wet oxidation method with $\mathrm{K}_{2} \mathrm{~S}_{2} \mathrm{O}_{8}$ (Menzel \& Vaccaro 1964). For the exact procedure see Cadée (1982).

Samples of $5.0 \mathrm{ml}$ were taken for enumeration of bacteria. Bacteria were counted using the Acridine Orange direct counting technique (Hobbie et al. 1977), following the procedures described by Van Duyl \& Kop (1990), except for the incubation step with tetrasodium pyrophosphate solution. At least 100 bacteria per sample were ranked in 18 different size classes to estimate 
the mean biovolume. Mean biovolume multiplied by the total number of bacteria in a sample yielded the total biovolume (Van Duyl \& Kop 1990). This total biovolume was converted to bacterial biomass (in $\mathrm{mg} \mathrm{C}$ ) using a conversion factor of $2.2 \times 10^{-10} \mathrm{mg} \mathrm{C} \mathrm{mm}^{-3}$ (Bratbak \& Dundas 1984).

Bacterial production was estimated from incorporation rates of ${ }^{3} \mathrm{H}$-labelled l-leucine (Kirchman et al. 1985). Duplicate samples of $5.0 \mathrm{ml}$ were incubated for $30 \mathrm{~min}$ at $12^{\circ} \mathrm{C}$, after addition of $0.1 \mathrm{nmol}$ leucine in aqueous solution, which consisted of 0.01 nmol [3, 4,5${ }^{3} \mathrm{H}$-L-leucine (114 to $177 \mathrm{Ci} \mathrm{mmol}{ }^{-1}$, Amersham) and $0.09 \mathrm{nmol}$ unlabeled leucine. A formaldehyde-killed control was run in parallel. Further sample processing was carried out as described in detail by Simon \& Azam (1989), except that we did not add ethylacetate to the samples.

Radioactivity was determined on an LKB 1211 Rackbeta liquid scintillation counter, using Filter Count (Canberra Packard) as the scintillation fluid. Bacterial production in $\mathrm{mg} \mathrm{C} \mathrm{l}^{-1} \mathrm{~d}^{-1}$ was calculated from the ${ }^{3} \mathrm{H}-\mathrm{l}$ leucine incorporation rates according to Simon \& Azam (1989), using a leucine:protein ratio of 0.073 , a protein: carbon weight ratio of 0.86 , and an internal isotope dilution factor of 2. External isotope dilution was not determined, and therefore the measurements will give minimal estimates of the bacterial carbon production.

The leucine concentration in the initial algal debris was measured by analysis of amino acids with HPLC (letswaart et al. 1994). The initial leucine concentration may give an indication of the height of the external isotope dilution factor in the early phase of the experiments.

In a separate degradation experiment, the concentration of acrylate was followed during the initial phase of the incubation. A mixture of algal debris collected during different Phaeocystis sp. blooms was used for this experiment. This debris was diluted 6-, 12-, and 18-fold with filtered sea water, and the diluted material was incubated in 3 well-aerated buckets at $12 \pm$ $0.5^{\circ} \mathrm{C}$ in darkness. These cultures were not inoculated with $5 \mu \mathrm{m}$ filtered sea water. Acrylate was measured on 3 successive days.

Modeling of POC and DOC decay. A multi-G model (Berner 1980) was applied to describe the decrease in the concentrations of POC and DOC. In multi-G models it is assumed that organic matter consists of $n$ different fractions, which all have a different first-order decay constant. The model used in this study consisted of 2 different fractions (MG-2 model).

The MG-2 model is written as:

$$
X(t)=a_{1} \mathrm{e}^{-b_{1} t}+a_{2} \mathrm{e}^{-b_{2} t}+\varepsilon_{t}
$$

where $X(t)=\mathrm{POC}$ or DOC concentration at time $t(\mathrm{mg}$ $\left.\mathrm{Cl}^{-1}\right), a_{1}=$ amount of POC or DOC in fraction 1 at $t=0$ (mg C l-1), $a_{2}=$ amount of POC or DOC in fraction 2 at $t=0\left(\mathrm{mg} \mathrm{C} \mathrm{l}^{-1}\right), b_{1}=$ decay constant of fraction $1\left(\mathrm{~d}^{-1}\right)$, $b_{2}=$ decay constant of fraction $2\left(\mathrm{~d}^{-1}\right)$, and $\varepsilon_{\mathrm{t}}=$ residual error ( $\mathrm{mg} \mathrm{C} \mathrm{^{-1 }}$ ).

The data were fitted with the SYSTAT statistical program, using the least-squares criterion for the best fit.

\section{RESULTS}

Differences were found in the composition of the undiluted algal debris from 15 April and 8 May (Table 1). For all the compounds that were measured, the highest concentrations were found in the 15 April debris. The proportions of amino acids and acrylate relative to the total organic carbon content were also highest in the 15 April debris. Only the $\mathrm{C}: \mathrm{N}$ ratio was higher in the 8 May debris.

The incubation experiments with the algal debris were carried out in duplicate. With a reliability of $95 \%$, most replicate data series did not show significant differences. Only the 2 data series for DOC in the May cultures and the 2 data series for bacterial numbers in the April cultures differed significantly from each other. Examination of the DOC data from the May cultures revealed that the shape of both curves was rather similar, but that one of the curves continuously showed slightly higher values than the other. A slightly higher initial concentration in this experiment could therefore have caused the observed significant difference. Hence, we present all data for POC and DOC as the means from duplicate experiments. The bacterial counts in the 2 replicate April cultures are presented separately.

The data for POC and DOC are presented as a percentage of the initial value to facilitate comparison of the curves. The data for POC (Fig. 1) show large ranges, especially in the beginning of the experiments. The initial POC values used for transformation of the data to percentages (Table 2) were therefore estimated from the total amount of organic carbon that was

Table 1. Composition of the undiluted algal debris

\begin{tabular}{|c|c|c|}
\hline & April & May \\
\hline Organic carbon content $\left(g \mathrm{Cl}^{-1}\right)$ & 5.80 & 3.85 \\
\hline Organic nitrogen content (g $\left.\mathrm{N}^{-1}\right)$ & 0.79 & 0.32 \\
\hline $\begin{array}{l}\text { Contribution of Phaeocystis sp. to } \\
\text { total organic carbon content }(\%)\end{array}$ & $\sim 50$ & $\sim 80$ \\
\hline Molar C:N ratio & 8.57 & 14.01 \\
\hline Acrylate $\left.(\mu \mathrm{mol} \mathrm{l})^{-1}\right)$ & 1600 & 96 \\
\hline Acrylate $\left(\mu \mathrm{mol} \mathrm{g} \mathrm{g}^{-1} \mathrm{C}\right)$ & 276 & 25 \\
\hline Total amino acids $\left(\mu \mathrm{mol} \mathrm{l}^{-1}\right)$ & 615 & 143 \\
\hline Total amino acids ( $\left.\mu \mathrm{mol} \mathrm{g}^{-1} \mathrm{C}\right)$ & 106 & 37 \\
\hline Leucine $\left(\mu \mathrm{mol} \mathrm{l}{ }^{-1}\right)$ & 8.8 & 3.6 \\
\hline
\end{tabular}



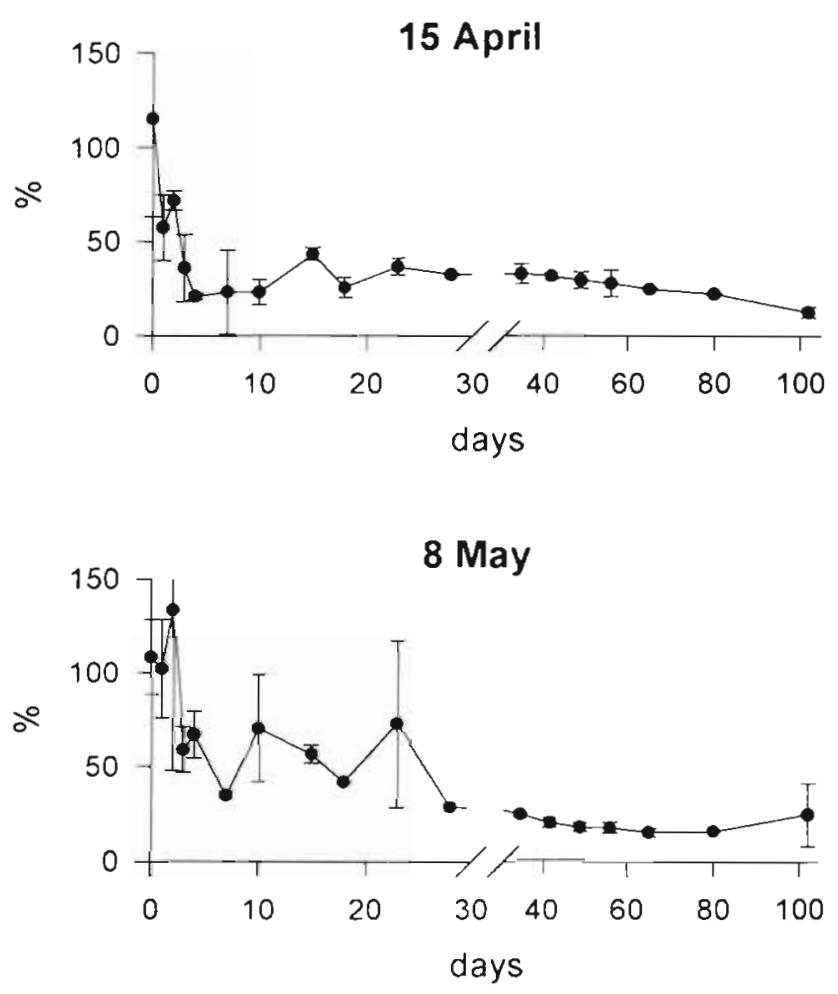

Fig. 1 Time course of the POC concentration in the experiments, expressed as a percentage of the initial value. Error bars indicate the range between 2 duplicate cultures

added to the culture (calculated from the data in Table 1) and the measured initial DOC concentrations (Fig. 2), which showed smaller ranges.

In all experiments, POC decreased rapidly during the first $4 \mathrm{~d}$ of the incubations. After the first $4 \mathrm{~d}$, the POC concentrations remained relatively constant for approximately $3 \mathrm{wk}$. Thereafter, POC decreased slowly until the end of the experiments. DOC (Fig. 2) also showed a rapid initial decrease.

The MG-2 model predictions closely matched the observed data for POC and DOC. Fig. 3 shows an example of the model fit for the DOC data in the April experiment. The estimated model parameters for all POC and DOC curves in Figs. 1 \& 2 are presented in Table 3 . A rapidly degradable fraction comprising 52

Table 2. Initial concentrations (in $\mathrm{mg} \mathrm{C}^{-1}$ ) of total, dissolved and particulate organic carbon (TOC, DOC and POC). TOC values are 10 -fold dilutions of the organic carbon content measured in the undiluted algal debris (Table 1)

\begin{tabular}{|lcc|}
\hline & April & May \\
\hline TOC & 580 & 385 \\
DOC & 85 & 80 \\
POC (TOC - DOC) & 495 & 305 \\
\hline
\end{tabular}
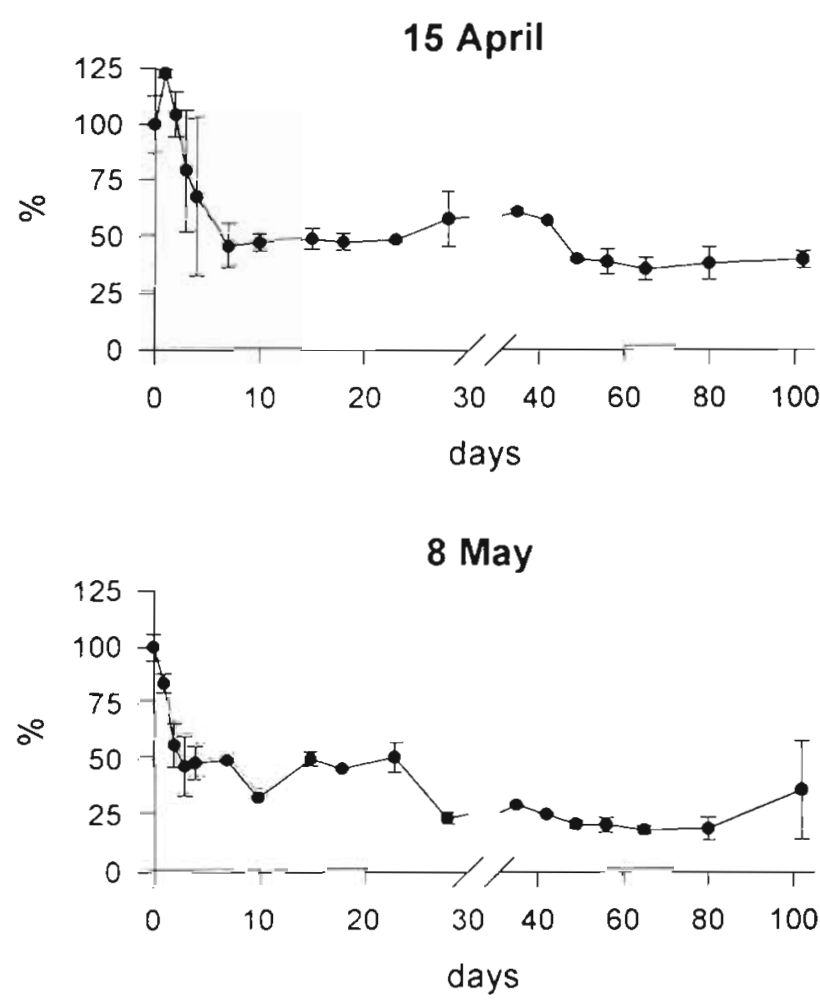

Fig. 2. Time course of the DOC concentration in the experiments, expressed as a percentage of the initial value. Error bars indicate the range between 2 duplicate cultures. The standard error for the triplicate DOC analyses was generally less than $10 \%$

to $70 \%$ of the total amount of POC or DOC was estimated by the MG-2 model. The decay constants for these rapid fractions indicate that 85 to $99 \%$ of the carbon in this fraction is mineralized within $5 \mathrm{~d}$. It should be noted here that the calculations of the rapid fractions were based on a few data points, with large ranges. Hence, the sizes of the rapid fractions suggested by the model must be considered as a rough estimate.

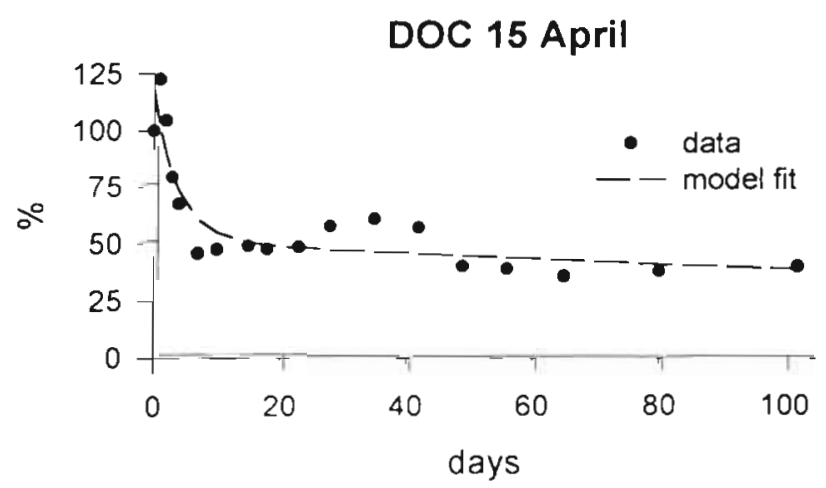

Fig. 3. Example of an MG-2 model fit. The model was fitted to the data for DOC in the April cultures 
Table 3 . Estimates of the parameters for the MG-2 models that were used to describe the decline in POC and DOC. The size of the 2 fractions $a_{1}$ and $a_{2}$ at $t=0$ and the decay constants $b_{1}$ and $b_{2}$ are presented. $X_{\text {ond }}$ concentrations of POC and DOC at the end of the experiments, expressed as percentages of the initial concentrations in Table 2

\begin{tabular}{|lcccc|}
\hline & POC April & POC May & DOC Aprll & DOC May \\
\hline$a_{1}\left(\mathrm{mg} \mathrm{C}^{-1}\right)$ & 400 & 200 & 59 & 42 \\
$a_{2}\left(\mathrm{mg} \mathrm{Cl}^{-1}\right)$ & 170 & 170 & 45 & 39 \\
$b_{1}\left(\mathrm{~d}^{-1}\right)$ & 0.9 & 0.76 & 0.43 & 0.72 \\
$b_{2}\left(\mathrm{~d}^{-1}\right)$ & 0.005 & 0.019 & 0.003 & 0.013 \\
$X_{\text {end }}(\%)$ & 21 & 8 & 39 & 13 \\
\hline
\end{tabular}

The decay constants of the slower fraction showed a difference between April and May, the latter showing the highest values. The decay constants were used to calculate the amounts of POC and DOC at the end of the incubations $\left(X_{\text {end }}\right)$. These end concentrations are expressed in Table 3 as percentages of the initial concentration (Table 2). A larger fraction of the 15 April material was left over at the end of the incubation period. Furthermore, it was calculated from the model results that after 1 yr, 19\% of the 15 April debris will still not have been mineralized. In contrast, more than $99 \%$ of the 8 May debris will have been mineralized after 1 yr.

The rapid initial decrease in POC and DOC was reflected in a rapid increase of the bacterial numbers (Fig. 4) and the bacterial biomass (Fig. 5) in the early phase of the experiments. Thereafter, numbers and biomass decreased to a minimal value around Day 15 , and subsequently increased to a second maximum between Day 20 and Day 30. This second maximum was lower than the initial high values. Unfortunately,

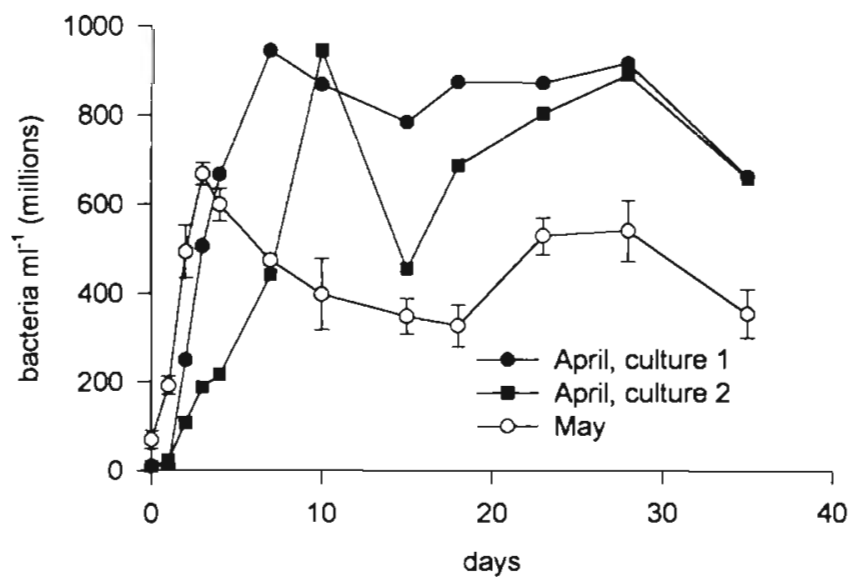

Fig. 4. Bacterial numbers. Error bars indicate the range between duplicate cultures. The standard error of the cell counts in a sample was generally less than $10 \%$. The bacterial numbers in the duplicate April cultures were significantly different from each other (Wilcoxon's signed rank test, p < $0.05)$. These results are presented as separate curves the samples that were taken after Day 35 were contaminated with other bacteria, but bacterial counts in a similar experiment (data not shown) showed that bacterial numbers remained relatively constant from that day on.

The distinction between a rapid and a slow fraction was not reflected in the bacterial production pattern (Fig. 6). Although the bacterial production increased rapidly in the initial phase, the initial production rate only slightly exceeded (May) or did not exceed (April) the relatively constant value that was measured throughout the rest of the experiments. However, the initial bacterial production rates may have been underestimated substantially. The leucine concentrations measured in the initial material (Table 1) indicate an additional 44 -fold dilution (April) or 18-fold dilution (May) of the added leucine with unlabeled leucine. Other experiments have shown that algal leucine is rapidly degraded (Osinga unpubl. results). Hence, the effect of algal leucine will be largest during the first few days of the incubations, when most of the algal leucine is still present.

The increase in bacterial biomass during the early phase of the incubations (the exponential growth phase of the bacteria) can be used as an alternative way of estimating the bacterial production. It must then be assumed that losses of bacterial biomass were negligible during this phase. Two factors able to reduce the bacterial biomass in marine waters are grazing by nano- and microzooplankton (Andersen \& Fenchel 1985, Van Duyl et al. 1990) and lysis induced by viruses (Proctor \& Fuhrman 1990, Heldal \& Bratbak 1991). In degradation experiments with marine phyto-

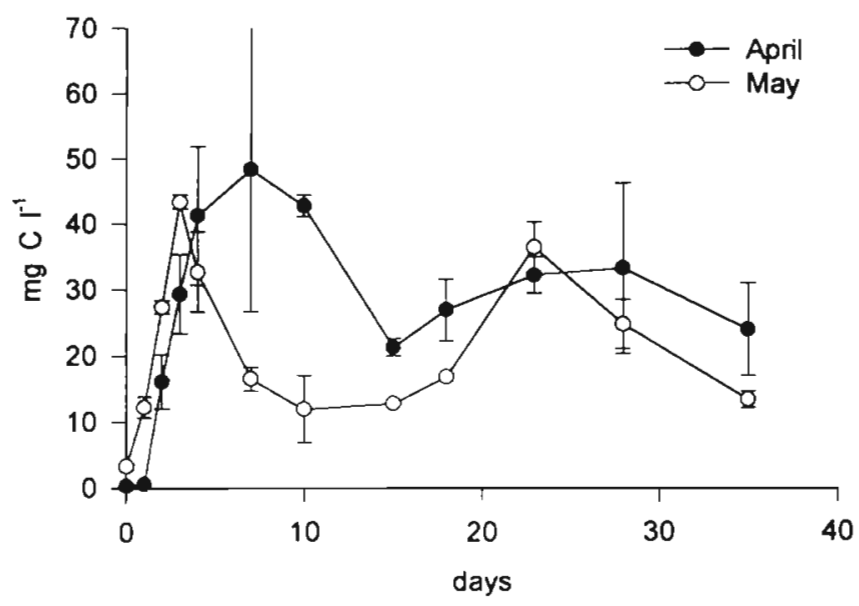

Fig. 5. Bacterial biomass calculated from the microscopic counts. Error bars indicate the range between duplicate cultures 


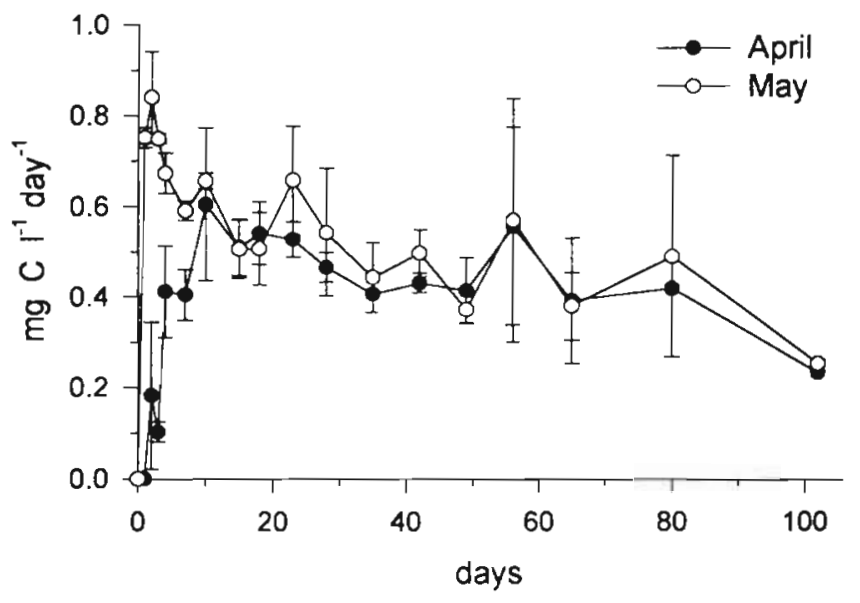

Fig. 6. Bacterial production rates. Error bars indicate the range between duplicate cultures

plankton debris, Newell et al. (1981) found that microheterotrophic arganisms showed a lag phase of at least $4 \mathrm{~d}$. Based on these observations, it can be assumed that in our experiments grazing losses of bacterial biomass will also have been low during the first $4 \mathrm{~d}$. It may
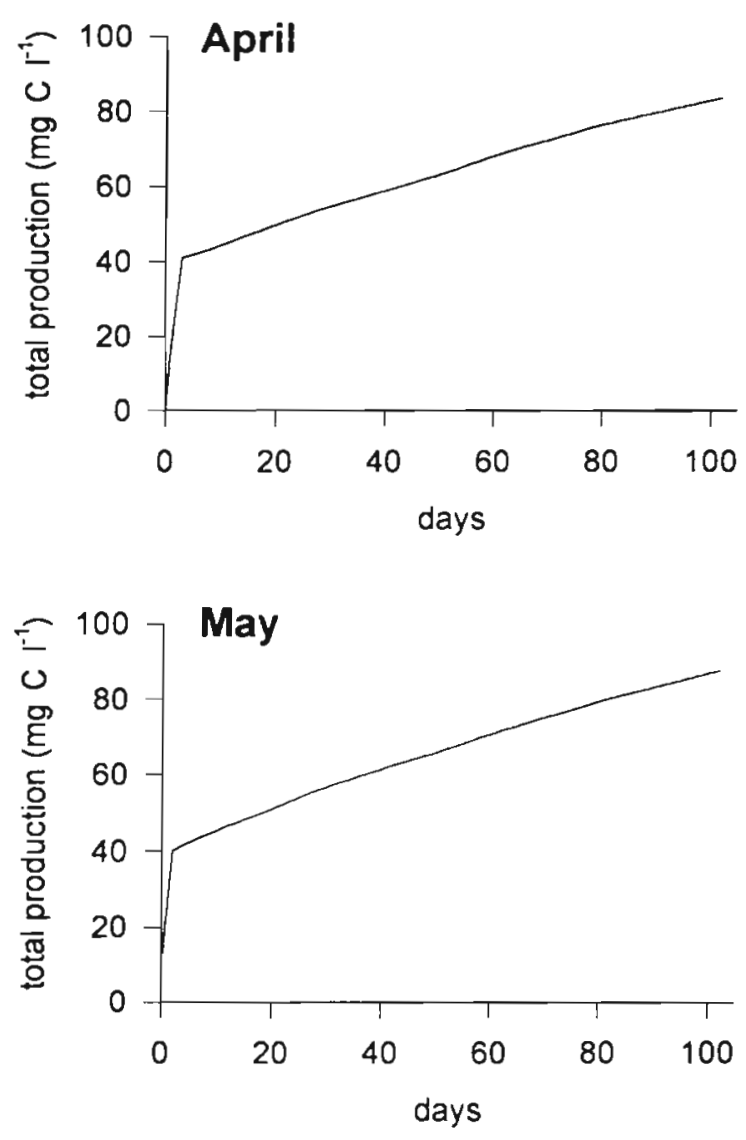

Fig. 7. Cumulative bacterial production based on both leucine incorporation measurements and bacterial biomass estimations (see text) also be assumed that viral attack of bacteria is relatively low in an exponentially growing population Hence, we used the increase in bacterial biomass to estimate the bacterial production during the exponential phase of the experiments

Fig. 7 shows the combined results of this increase in biomass (Days 0 to 4 in the April experiment; Days 0 to 3 in the May experiment) and bacterial production measured with leucine incorporation (remaining days). Fig. 7 shows cumulative values: the daily production is constantly added to the previously produced bacterial carbon. The curves in Fig. 7 show a pattern that is inversely related to the observed decreases in POC and DOC in Figs. 1 \& 2: a short period of high production in the beginning of the experiments, followed by a long period of much lower production. Apparently, $50 \%$ of the total cumulative bacterial carbon was produced during the first $4 \mathrm{~d}$ of the experiments. It should be noted here again that the leucine incorporation measurements give minimal estimates. Hence, the bacterial production during the remaining $97 \mathrm{~d}$ may have comprised more than $50 \%$ of the total production.

The results of the acrylate measurements are presented in Fig. 8. It is clear that acrylate is very rapidly degraded: even in the least-diluted experiment, the acrylate concentration had already decreased below the detection limit after $3 \mathrm{~d}$.

\section{DISCUSSION}

The rapid bacterial response and the rapid decrease in organic matter concentration in our experiments showed that organic material produced during the spring bloom of Phaeocystis sp. in the southern North Sea is a good substrate for heterotrophic bacteria. This provides experimental evidence for the ideas of Thingstad \& Billen (1994): the fact that Phaeocystis spp. colonies in the exponential phase of a bloom are

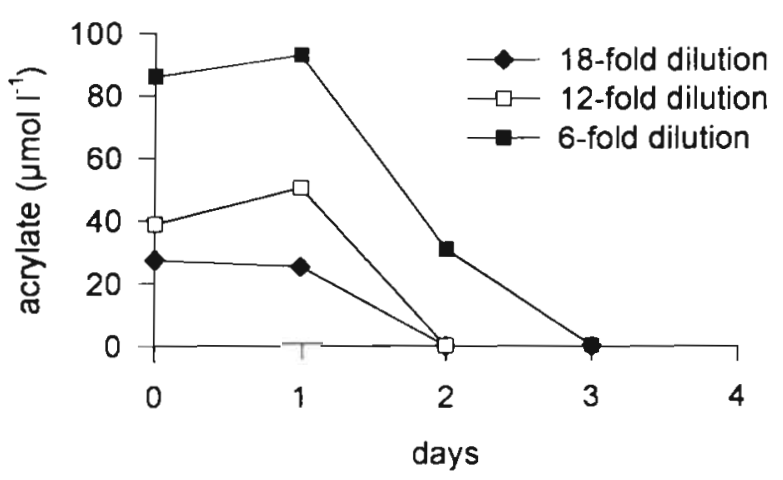

Fig. 8. Acrylate concentrations in 3 degradation experiments with diluted algal material (6-, 12- and 18-fold dilutions).

Concentrations were measured on 3 successive days 
almost free of bacteria is not due to a low degradability of the material, but to other factors, which remain to be identified

Antibiotic substances are not likely to delay the degradation of dead algal material. The concentrations of potential antibiotics were not high enough to prevent the rapid bacterial response in our experiments. Initially, acrylate was present in the cultures in concentrations that are able to inhibit bacterial activity significantly (cf. Slezak et al. 1994). In our control experiments, however, it turned out that this compound was rapidly degraded, even in the culture with the highest initial concentration. Hence, inhibition of bacteria by acrylate or other antibiotic compounds is not likely to explain the accumulation of organic material that was observed at the end of a Phaeocystis pouchetii bloom by Eberlein et al. (1985). On the other hand, the concentrations of these compounds inside living Phaeocystis spp. cells or colonies may be considerably higher than the concentrations in the material used for the experiments. Therefore, we cannot fully exclude the possibility that antibiotic compounds protect the intact Phaeocystis sp. cells or colonies against bacterial attack.

The algal material was found to consist of a rapidly degradable fraction and a slowly degradable fraction. This pattern seems to be common for the degradation of organic substrates: it was found in other degradation experiments with microalgae (e.g. Newell et al. 1981, Pett 1989, Van Raaphorst et al. 1992), and also in degradation experiments with straw in terrestrial soils (Cheshire et al. 1979). Newell et al. (1981), who carried out degradation experiments with 6 different phytoplankton species, found that $30.8 \%$ of the algal carbon was mineralized within $3 \mathrm{~d}$, indicating that the rapidly degradable fraction can be considerable in size. The size of the rapid fractions in our experiments could not be accurately estimated by the MG-2 model, but the model calculations showed that the slowly degradable fractions comprised about $50 \%$ of the initial algal carbon, leaving another 50\% for the rapid fractions.

According to Table 2, 50\% of the initial algal carbon equals $290 \mathrm{mg} \mathrm{C} \mathrm{l}^{-1}$ in the April cultures and $195 \mathrm{mg} \mathrm{C}$ $1^{-1}$ in the May cultures. In both experiments, a bacterial biomass of $40 \mathrm{mg} \mathrm{C}^{-1}$ was produced during the degradation of this labile carbon. A bacterial carbon conversion efficiency (BCCE) can be calculated from these values as follows: the percentage of algal organic carbon that is incorporated into bacterial biomass is equal to the quotient of the bacterial biomass production and the total bacterial carbon demand (i.e. production + respiration) multiplied by 100 . This calculation yields BCCEs of 12 and $17 \%$ for April and May, respectively. These values are in good agreement with the results of Newell et al. (1981), who found a BCCE of $9.8 \%$ for the rapidly degradable fraction in their experiments. We conclude that labile algal material is rapidly degraded, but inefficiently used for biomass production.

The importance of estimating the BCCE has recently been emphasized by Jahnke \& Craven (1995), who observed a large variation in the efficiencies reported in the literature, which may be due to either physiological, ecological or methodological differences. We agree with their conclusion that extrapolation of bacterial biomass production measurements to the ecosystem level should not be done without additional measurements of bacterial $\mathrm{CO}_{2}$ production or oxygen consumption. Degradation studies by Bauerfeind (1985) and Bjørnsen (1986), who did use respiration measurements, gave BCCE values around $20 \%$, which are much more in agreement with our results than the $50 \%$ efficiency that is often used in the literature to convert bacterial production to carbon fluxes (Cole et al. 1988, Ducklow \& Carlson 1992).

Due to the uncertainty in the leucine incorporation measurements, BCCEs for the resistant fractions could not be accurately estimated. It seemed, however, that they were higher than the BCCEs for the rapidly degradable fractions: the decrease in the carbon concentration between Days 5 and 102 was smaller than the decrease during the first $5 \mathrm{~d}$, but the total bacterial carbon production was at least similar.

After the initial phase, the measured bacterial production did not lead to an equivalent increase in bacterial biomass. Losses of bacterial biomass must have balanced the production. As was mentioned earlier, 2 important factors that control the bacterial biomass in. marine waters are grazing by nano- and microzooplankton and lysis induced by viruses. In our highly eutrophic cultures, viruses may have been the dominant loss factor: according to Weinbauer \& Peduzzi (1995), the impact of viruses on bacterial biomass increases under more eutrophic conditions. In systems with a high rate of virus-induced lysis of bacterial cells, rapid recycling of bacterial biomass may take place (Bratbak et al. 1990). Cryptic growth will be quantitatively important in such systems. Bacterial carbon can be very labile (Novitsky 1986), and may be a qualitatively better food source for bacteria than algal material, enabling a higher BCCE. In our experiments, an efficient and quantitatively important cryptic growth may have increased the overall BCCE during the degradation of the slowly degradable fraction. The microbial degradation of the refractory algal material itself may be much less efficient.

Comparison of the April and May cultures showed that the May material is further degraded than the April material, which implies that more refractory material is produced in earlier stages of the bloom. It 
will take several years before this refractory material is completely degraded. Hence, this material may contribute significantly to the DOC pool in the sea

The changes in degradability that occur during the course of the bloom will be due to changes in the chemical composition of the algal material. These can be considerable during Phaeocystis-dominated blooms (Veldhuis et al. 1986). Here, we found large differences between April and May in the ratio of carbon to nitrogen, amino acid concentrations and acrylate concentrations. These chemical changes may be due both to the observed shift in species composition and to the physiological stage of the dominant species, Phaeocystis $\mathrm{sp}$. A chemical characterization of the material at the start and at the end of the incubation may provide more insight into the type of compounds that form the refractory part, while chemical studies on monospecific algal cultures may teach us more about the production of these compounds by different algal species.

The debris with the highest $\mathrm{C}: \mathrm{N}$ ratio (May) was degraded most efficiently, which is in contrast to the general concept that the $\mathrm{C}: \mathrm{N}$ ratio is negatively correlated with the BCCE (Ducklow \& Carlson 1992). This may be due to an increased production of carbon-rich, highly energetic sugars by Phaeocystis sp. during the course of the bloom. For instance, Janse et al. (1996) found that the glucose content of Phaeocystis globosa material from the North Sea was highly variable. An increased glucose production in combination with the increased dominance of Phaeocystis sp. in May may have increased the $\mathrm{C}: \mathrm{N}$ ratio, but may have increased the biodegradability as well.

Acknowledgements. We thank Rikus Kloosterhuis and Jan Hegeman for their assistance with the carbon analyses. Arjen Kop and Jos Smit collected the algal debris. This study was funded by the Dutch National Research Program, project NOLK/026/90 and by the European Community, project CT93-0326. This is NIOZ publication number 3141

\section{LITERATURE CITED}

Andersen P, Fenchel T (1985) Bacterivory by microheterotrophic flagellates in sea water samples. Limnol Oceanogr 30:198-202

Bauerfeind S (1985) Degradation of phytoplankton detritus by bacteria: estimation of bacterial consumption and respiration in an oxygen chamber. Mar Ecol Prog Ser 21:27-36

Berner RA (1980) Early diagenesis: a theoretical approach. Princeton University Press, Princeton

Bjørnsen PK (1986) Bacterioplankton growth yield in continuous seawater cultures. Mar Ecol Prog Ser 30:191-196

Bratbak G, Dundas I (1984) Bacterial dry matter content and biomass estimations. Appl Environ Microbiol 48:755-757

Bratbak G. Heldal M, Norland S, Thingstad TF (1990) Viruses as partners in spring bloom microbial trophodynamics. Appl Environ Microbiol 56:1400-1405

Cadée GC (1982) Tidal and seasonal variation in particulate and dissolved organic carbon in the western Dutch Wad- den Sea and Marsdiep tidal inlet. Neth J Sea Res 15 $228-249$

Cadée GC. Hegeman J (1986) Seasonal and annual variation in Phaeocystis pouchetii (Haptophyceae) in the westernmost inlet of the Wadden Sea during the 1973 to 1985 period. Neth J Sea Res 20:29-36

Cadée GC, Hegeman J (1993) Persisting high levels of primary production at declining phosphate concentrations in the Dutch coastal area (Marsdiep). Neth J Sea Res 31:147-152

Cheshire MV, Sparling GP, Inkson RHE (1979) The decomposition of straw in soil. In: Grossbeard E (ed) Straw decay and its effect on disposal and utilization. John Wiley \& Sons, Chichester, p 65-71

Cole JJ, Findlay S, Pace ML (1988) Bacterial production in fresh and saltwater ecosystems: a cross-system overview. Mar Ecol Prog Ser 43:1-10

Ducklow HW, Carlson CA (1992) Oceanic bacterial production. Adv Microb Ecol 12:113-181

Eberlein K, Leal MT, Hammer KD, Hickel W (1985) Dissolved organic substances during a Phaeocystis pouchetii bloom in the German Bight (North Sea). Mar Biol 89:311-316

Heldal M, Bratbak G (1991) Production and decay of viruses in aquatic environments. Mar Ecol Prog Ser 72:205-212

Hobbie JE, Daley RJ, Jasper S (1977) Use of nucleopore filters for counting bacteria by epifluorescence microscopy. Appl Environ Microbiol 33:1225-1228

Ietswaart T, Schneider PJ, Prins RA (1994) Utilization of organic nitrogen sources by two phytoplankton species and a bacterial isolate in pure and mixed cultures. Appl Environ Microbiol 60:1554-1560

Jahnke RA, Craven DB (1995) Quantifying the role of heterotrophic bacteria in the carbon cycle: a need for respiration rate measurements. Limnol Oceanogr 40:436-441

Janse I, Van Rijssel M, Gottschal JC. Lancelot C, Gieskes WWC (1996) Carbohydrates in the North Sea during spring blooms of Phaeocystis: a specific fingerprint. Aquat Microb Ecol 10:97-103

Kirchman DL, K'nees E, Hodson RE (1985) Leucine incorporation and its potential as a measure for protein synthesis by bacteria in natural aquatic systems. Appl Environ Microbiol 49:599-60?

Lancelot C, Billen G, Sournia A, Weisse T, Colijn F, Veldhuis M, Davies A, Wassmann P (1987) Phaeocystis blooms and nutrient enrichment in the continental coastal zone of the North Sea. Ambio 16:38-46

Lancelot C, Mathot S (1987) Dynamics of a Phaeocystis-dominated spring bloom in Belgian coastal waters. I. Phytoplankton activities and related parameters. Mar Ecol Prog Ser 37:239-248

Lancelot C, Wassmann P (eds) (1994) Ecology of Phaeocystisdominated ecosystems. J Mar Syst 5:1-100

Menzel DW, Vaccaro RF (1964) The measurement of dissolved and particulate carbon in sea water Limnol Oceanogr 9:138-142

Newell RC, Lucas MI, Linley EAS (1981) Rate of degradation and efficiency of conversion of phytoplankton debris by marine microorganisms. Mar Ecol Prog Ser 6:123-136

Novitsky JA (1986) Degradation of dead microbial bıomass in a marine sediment. Appl Environ Microbiol 52:504-509

Osinga R, Kwint RLJ, Lewis WE, Lindeboom HJ, Kraay GW, Lont JD, Van Duyl FC (1995) Production and fate of dimethylsulfide and dimethylsulfoniopropionate in pelagic mesocosms: the role of sedimentation. Mar Ecol Prog Ser 131:275-286

Pett RJ (1989) Kinetics of microbial mineralization of organic carbon from detratal Skeletonema costatum cells. Mar Ecol Prog Ser 52:123-128 
Proctor LM, Fuhrman JA (1990) Viral mortalıty of marine bacteria and cyanobacteria. Nature 343:60-62

Sieburth JM (1960) Acrylic acid, an 'antibiotic' principle in Phaeocystus blooms in Antarctic waters. Science 132 676-677

Simon M. Azam F (1989) Protein content and protein synthesis rates of planktonic marine bacteria. Mar Ecol Prog Ser 51:201-213

Slezak DM, Puskaric S, Herndl GJ (1994) Potential role of acrylic acid in bacterioplankton communities in the sea. Mar Ecol Prog Ser 105:191-197

Thingstad F, Billen G (1994) Microbial degradation of Phaeocystis matenal in the water column. J Mar Syst 5:55-65

Van Boekel WHM (1993) Interactions of Phaeocystis sp. with organic compounds and the microbial foodweb. PhD thesis, University of Groningen

Van Duyl FC, Bak RPM, Kop AJ, Nieuwland G (1990) Bacteria, auto- and heterotrophic nanoflagellates, and their relations in mixed, frontal and stratified waters of the North Sea. Neth J Sea Res 26:97-109

Van Duyl FC, Kop AJ (1990) Seasonal patterns of bacterial production and biomass in intertidal sediments of the western Dutch Wadden Sea. Mar Ecol Prog Ser 59:249-261

Responsible Subject Editor: F. Thingstad, Bergen, Norway
Van Duyl FC, Kop AJ, Kok A. Sandee AJJ (1992) The impact of organic matter and macrozoobenthos on bacterial and oxygen variables in marine sediment boxcosms. Neth $\mathrm{J}$ Sea Res 29:343-355

Van Raaphorst W, Kloosterhuis HT, Berghuis EM, Gieles AJ, Malschaert JFP, Van Noort GJ (1992) Nitrogen cycling in two sediments of the southern North Sea (Frisian Front, Broad Fourteens): field data and mesocosm results. Neth J Sea Res 28:293-316

Veldhuis MJW (1987) Ecophysiology of Phaeocystis pouchetii. PhD thesis, University of Groningen

Veldhuis MJW. Admiraal W, Colijn F (1986) Chemical and physiological changes of phytoplankton during the spring bloom dominated by Phaeocystis pouchetii (Haptophyceae): observations in Dutch coastal waters of the North Sea. Neth J Sea Res 20:49-60

Verardo DJ, Froelich PN, McIntyre A (1990) Determination of organic carbon and nitrogen in sediments using a Carlo Erba NA-1500 analyzer. Deep Sea Res 37:157-165

Weinbauer MG, Peduzzi P (1995) Significance of viruses versus heterotrophic nanoflagellates for controlling bacterial abundance in the northern Adriatic Sea. J Plankton Res 17:1851-1856

Manuscript first received: January 9, 1996

Revised version accepted: October 3,1996 